\title{
Effect of the Addition of Catfish Meat on Improving of Jerked Meat Protein from Cassava Leaves (Manihot utilissima)
}

\author{
Sahadi Didi Ismanto ${ }^{\#}$, Surini Siswardjono ${ }^{\#}$ and Silvia Nengsih ${ }^{\#}$ \\ \# Faculty of Agricultural Technology, Andalas University, Padang, Indonesia \\ E-mail: sahadididiismanto@gmail.com
}

\begin{abstract}
This study aimed to determine the effect of catfish meat to increase protein of jerked meat cassava leaves (Manihot utilissima) and to find the best products from cassava leaves jerked meat. This research was conducted at the Laboratory of Engineering and Process Technology, Chemical Agricultural Products and Nutrition Department of Agricultural Technology Andalas University from August to October 2014. The method used in this study experimental method, using a completely randomized design (CRD) with 6 treatments and 3 replications. The treatments are the addition of catfish meat, respectively : 37.5 $\%(\mathrm{~A}), 50 \%(\mathrm{~B}), \mathbf{6 2 . 5} \%(\mathrm{C}), \mathbf{7 5} \%(\mathrm{D}), \mathbf{8 7 . 5} \%(\mathrm{E})$, and $100 \%(\mathrm{~F})$. Data was processed with statistically by using ANOVA which was followed by Duncan 's New Multiple Range Test (DNMRT) at the 5\% significance level. The results of this study showed that the addition of catfish meat were very significantly effect on the improvement of cassava leaves protein jerked ranged from $25.9 \%$ $38.08 \%$, decreasing water content that ranges between $7.58 \%-9.16 \%$, increasing ash content which ranged between $1.15 \%-1.54$ $\%$, and fat content ranged from $28.83 \%-33.33 \%$. Based on sensory analysis, the best product is treatment $B$ ( the addition of 50 $\%$ of catfish meat), where color was preferred by $70 \%$ panelist, flavor by $75 \%$, taste by $90 \%$, and texture by $90 \%$ of panelist.
\end{abstract}

Keywords - Cassava Leaves, Catfish , Jerked Meat , Protein

\section{INTRODUCTION}

Leaves of cassava (Manihot utilissima) is one of the vegetables that contain minerals and vitamins that are good for the growth and health of the body. The level of consumption of cassava leaves as balanced nutrition is getting increased in the community. Vegetables are derived from plant cassava tubers, besides inexpensive and easily obtainable and easily cultivated. Cassava leaves are eaten usually used as a vegetable or as an ingredient, and processed into snacks is a good source of protein. Development of new ways of processing cassava leaves to be done to increase the economic value and as an effort to diversification (diversification of food).

The latest innovation is made jerky cassava leaves, cassava leaves jerky relatively safer for those who should not eat meat because of certain diseases or for vegetarians. Cassava leaves are very easy to find. Cassava leaves contain vitamins $\mathrm{A}, \mathrm{B} 1$ and $\mathrm{C}$, Calcium, Calories, phosphorus, protein, fat, carbohydrate, and Iron substances.

Catfish is a kind of fish that live in fresh water catfish. That fish easily recognizable because of his slick, slightly flattened elongated, and has a long mustache, sticking out from around the mouth.
Catfish have good nutritional content as source of energy, fat, calcium $(\mathrm{Ca})$, phosphorus $(\mathrm{P})$, iron $(\mathrm{Fe})$, Sodium, Thiamine (B1), riboflavin (B2), and Niacin. Nutrient content contained in catfish have an important role in the maintenance of body functions. Catfish or similar fish that live in fresh water is much to like because it tastes delicious and tasty, but not everyone liked the grounds catfish like to eat rotten food. Catfish is one of the ingredients are easy nutritious meal is served as a side dish. Nutrient content catfish comparable to other fish meat. Some species of fish, including catfish higher in protein and better than the meat of animals. Catfish increased nutritional value when processed properly

In Indonesia food jerky already familiar with an area, can even be categorized as typical food archipelago. Generally jerky made from beef preserved by means of dried and dried under the sun. Generally jerky flavoured with tamarind, salt and spices - other spices. But not everyone can eat meat, in addition to relatively high prices are also many fake meat circulating in the community, so that the need for a new innovation to create foods that are rich in protein. Cassava leaf protein content compared with other vegetables, but when compared to the protein in beef jerky, protein contained in cassava leaves still less, to increase the protein 
content in cassava leaves jerky then be added to the meat catfish, so that the protein jerky increased cassava leaves.

The purpose of this study is to determine the effect of catfish meat to increased protein cassava leaves (Manihot utilissima). And to find the best jerky products with the addition of cassava leaf fillet catfish meat based sensory analysis.

\section{RESEARCH METHODS}

\section{A. Place and Time Research}

This research has been carried out in the Laboratory of Technology and Process Engineering, Chemical Agricultural Products, Nutrition Department of Agricultural Technology, Andalas University from August to October 2014.

\section{B. Materials and Equipment}

Raw materials used in this study is 1200 grams of cassava leaves and catfish as much as 825 grams. Chemicals used were distilled water, $\mathrm{H} 2 \mathrm{SO} 4, \mathrm{H} 3 \mathrm{BO} 3$, methyl red indicator, $\mathrm{NaOH}$, and Hexane. Tool - a tool used consists of a stove, a pot, pan, bowl, spoon stirrer, trays, knives, grounding, kjedahl flask, $125 \mathrm{ml}$ Erlenmeyer flask, measuring cups, a set of tools soxlet, filter paper, porcelain bowls, electric oven, decicator, tweezers, analytical balance, combustion cup, paper labels.

\section{Research Design}

The design used in this research is completely randomized design (CRD), which consists of 6 treatments and 3 times replication. The treatment is given in this study are:

$\mathrm{A}=$ Addition catfish meat $37.5 \%$

$\mathrm{B}=$ The addition of Meat of Catfish $50 \%$

$\mathrm{C}=$ The addition of Meat of Catfish $62.5 \%$

$\mathrm{D}=$ The addition of Meat of Catfish $75 \%$

$\mathrm{E}=$ The addition of Meat of Catfish $87.5 \%$

$\mathrm{F}=$ The addition of Meat of Catfish $100 \%$

Data were analyzed statistically using ANOVA, and if significantly different test followed by Duncan's New Multiple Range Test (DNMRT) at the 5\% significance level.

\section{Implementation Research}

\section{Making Jerky Cassava Leaves}

1) Preparation of raw materials. The raw materials used are cassava leaves and catfish. Mashed cassava leaves that have weighed weighing 1200 grams, and is divided into 6 sections.

2) Addition of catfish and mixing meat seasoning. Cassava leaf that has been divided into six parts were added with Meat of Catfish that has been refined with each - each treatment (A) $37.5 \%=75 \mathrm{gram}$, (B) 50\% = 100gram, (C) $62.5 \%=125 \mathrm{gram},(\mathrm{D}) 75 \%=150 \mathrm{gram},(\mathrm{E}) 87.5 \%=$ 175 gram, $(\mathrm{F}) 100 \%=200$ gram, then added into each treatment with herbs such as ginger 20 grams, 3 grams of coriander, pepper 2 grams, onions red 30, 5 salt, garlic 25 grams, 40 grams of tapioca, lime leaves 1 sheet, bay leaf 1 sheet, 1 stalk lemongrass, 5 grams of granulated sugar and 1 egg, stir until homogeneous.3.

3) Steaming, Mixture of cassava leaves, meat catfish, and seasoning of boxing rounded adults then steamed for 30 minutes. The purpose of steaming in order to facilitate the incision.

\section{4) Excision}

5) Drying up to $25 \%$ moisture content, Drying is done by using the oven $50^{\circ} \mathrm{C}$ temperature for 9 hours.

6) Frying. The last process in the manufacture of jerky that is frying. Frying is done until a brownish colour.

\section{E. Formulation Making Jerky Cassava Leaves (Salsabilla)}

This formulation is taken from the making jerky Salsabilla cassava leaves are housed in oblong Muktitama, Turmeric River, Sangir cowboy hall. Formulation of making jerky can be seen in Table 1 .

TABLE I

FORMULATION INGREDIENTS MAKING JERKY CASSAVA LEAVES

\begin{tabular}{|l|c|c|c|c|c|c|}
\hline \multirow{2}{*}{\multicolumn{1}{c|}{ Ingredients }} & \multicolumn{7}{c|}{ Formula } \\
\cline { 2 - 7 } & $\mathrm{A}$ & $\mathrm{B}$ & $\mathrm{C}$ & $\mathrm{D}$ & $\mathrm{E}$ & $\mathrm{F}$ \\
\hline Cassava leaves (g) & 200 & 200 & 200 & 200 & 200 & 200 \\
\hline Meat of Catfish (g) & 75 & 100 & 125 & 150 & 175 & 200 \\
\hline Salt (g) & 10 & 10 & 10 & 10 & 10 & 10 \\
\hline Tapioca Starch (g) & 50 & 50 & 50 & 50 & 50 & 50 \\
\hline Shallots (g) & 30 & 30 & 30 & 30 & 30 & 30 \\
\hline Garlic (g) & 25 & 25 & 25 & 25 & 25 & 25 \\
\hline Coriander (g) & 3 & 3 & 3 & 3 & 3 & 3 \\
\hline Pepper (g) & 2 & 2 & 2 & 2 & 2 & 2 \\
\hline Ginger (g) & 20 & 20 & 20 & 20 & 20 & 20 \\
\hline Sugar (g) & 5 & 5 & 5 & 5 & 5 & 5 \\
\hline Eggs (pieces) & 1 & 1 & 1 & 1 & 1 & 1 \\
\hline Salam leaf (sheet) & 1 & 1 & 1 & 1 & 1 & 1 \\
\hline Lemongrass (rod) & 1 & 1 & 1 & 1 & 1 & 1 \\
\hline Orange leaves (sheets & 1 & 1 & 1 & 1 & 1 & 1 \\
\hline Source: Modified Sals & & & & & & \\
\hline
\end{tabular}

Source: Modified Salsabilla

\section{RESULTS AND DISCUSSION}

\section{A. Analysis of Raw Materials Cassava Leaves Jerky}

Analysis of raw materials jerky cassava leaves include moisture content, ash, protein, and fat, can be seen in table 2 .

TABLE II

RESUlts OF CHEMICAL ANALYSIS JERKy RAW CASSAVA LEAVES

\begin{tabular}{|l|c|c|}
\hline \multicolumn{1}{|c|}{ Analysis } & Cassava Leaves (\%) & Meat of Catfish (\%) \\
\hline Water Content & 77,80 & 79 \\
\hline Ash Content & 0,86 & 1,10 \\
\hline Protein & 6,28 & 18,42 \\
\hline Fat & 1,31 & 1.22 \\
\hline
\end{tabular}

Cassava leaves are used in this study contains $77.80 \%$ water content is higher than the water content of cassava leaves on Indonesian food composition table that is $77.20 \%$. Meat of Catfish were used in the study contain levels water $79 \%$ higher than the water content of catfish on Indonesian food composition table that is $78.5 \%$. Ash content of cassava leaves are used in this study is $0.86 \%$, and catfish meat containing $1.10 \%$ ash content. Cassava leaf protein used in this study contains is $6.28 \%$, lower than the Indonesian food composition table is $6.80 \%$. Meat of Catfish are used in protein $18.42 \%$, lower than the proteins in food composition tables Indonesia is $18.7 \%$. Fat cassava leaves are used in this study contains $1.31 \%$, higher than the cassava leaf fat in 
food composition tables Indonesia, $1.20 \%$, fat in Meat of Catfish were used in this study contains $1.22 \%$, higher when compared with meat fat catfish on Indonesian food composition table is $1.10 \%$.

The difference in the results of chemical analysis of raw materials obtained may be due to the possibility of varieties of cassava leaves and catfish are different, and come from different environments. According to [1], environmental conditions greatly affect the levels of plant nutrients.

\section{B. Characteristics of Chemical Jerky Cassava Leaves}

Chemical analyzes were carried out on beef jerky products Cassava leaves are testing moisture content, ash content, protein content, and fat content.

\section{1) Analysis of Moisture}

Statistical test results to the analysis of water content jerky with the addition of Meat of Catfish treatment was not significantly different at the significance level $\alpha=5 \%$ of the water content of cassava leaves produced jerky. Value average moisture content of cassava leaf jerky can be seen in Table 3.

TABLE III

JeRKy Water CONTENT ANALYSIS OF CASSAVA LEAVES

\begin{tabular}{|l|c|}
\hline Treatment & Water Content (\%) \\
\hline F (The addition of Meat of Catfish 100 \%) & 7,58 \\
\hline E (The addition of Meat of Catfish 87,5\%) & 7,79 \\
\hline D (The addition of Meat of Catfish 75\%) & 8.40 \\
\hline C (The addition of meat catfish62,5\%) & 8,45 \\
\hline B (The addition of Meat of Catfish 50 \%) & 8,51 \\
\hline A(The addition of Meat of Catfish 37,5\%) & 9,16 \\
\hline CV $=9,31 \%$ & \\
\hline
\end{tabular}

Based on Table 2 shows the water content of cassava leaf jerky with the addition of Meat of Catfish ranged from 7, 58 to $9.16 \%$. The highest water content contained in treatment A (Meat of Catfish 37.5\%) with an average value of $9.16 \%$ while the water content was lowest for the treatment jerky $\mathrm{F}$ (Meat of Catfish 100\%) with an average value of $7.58 \%$.

In Table 2 it can be seen that increasing the formula catfish meat is added to the cassava leaves will reduce the water content of cassava leaves produced jerky. This is due to the presence of water bound to the protein, because the protein in Meat of Catfish is high at $18.96 \%$. Proteins can bind water molecules by hydrogen bonds are strong, this ability due to hydrophilic proteins.

The water content of the material is calculated based on free water and bound water physically because it has properties more easily evaporated compared with chemically bound water. Based upon the degree of entanglement of water in the food, the water is divided into four types, namely chemically bound water, physically bound water, free water and bound water on the surface of food that is not attached at all the food matrix.

The water content of the raw material cassava leaves and catfish before processing tends to be high. After processing the moisture content decreases jerky, this is because at the time of the processing is done drying jerky with $55^{\circ} \mathrm{C}$ temperature for 8 hours. The temperature used for drying is not more than $70^{\circ} \mathrm{C}$. Drying with high temperature will lead to case hardening. The purpose of drying is to reduce the water content in the material to a certain extent by evaporating water in the material by using heat energy. [5].

Winarno [10] states that, drying is a method to remove or eliminate some of the water from a substance by evaporating water by using heat energy, usually the water content of the material is reduced to the extent microorganisms can not grow.

Suharyanto [9] states that, drying leads to reduced water content of the meat, causing ingredients other materials such as proteins, carbohydrates and fats in higher concentrations. According to SNI [8], a maximum moisture content of $12 \%$ jerky thus Jerky water content of cassava leaves are produced throughout the treatment has met the standards.

\section{2) Ash Content Analysis}

The results of statistical tests on the ash content analysis by treatment with the addition of beef jerky catfish were not significantly different at the significance level $\alpha=5 \%$ of the ash content of cassava leaves produced jerky. The average value of ash content in cassava leaves jerky meat with the addition of catfish can be seen in Table 4 .

TABLE IV

ASH CONTENT ANALYSIS JERKy CASSAVA LEAVES

\begin{tabular}{|l|c|}
\hline Treatment & Ash Content (\%) \\
\hline A (The addition of Meat of Catfish 37.5 \%) & 1,15 \\
\hline B (The addition of Meat of Catfish 50\% ) & 1,22 \\
\hline C (The addition of Meat of Catfish 62.5\%) & 1,36 \\
\hline D (The addition of Meat of Catfish 75\% ) & 1,46 \\
\hline E (The addition of Meat of Catfish $87.5 \%$ ) & 1,49 \\
\hline F (The addition of Meat of Catfish 100 \% ) & 1,54 \\
\hline CV $=11,98 \%$ & \\
\hline
\end{tabular}

The results of the analysis of Table 3 shows that the difference between the treatments did not differ much this means the ash content analysis results are given no real effect on cassava leaves produced jerky. Ash different jerky is influenced by the raw materials used, the ash content of catfish meat is higher than the ash content of cassava leaves, so the ash content jerky tends to increase with increasing concentration of catfish meat. Ash content with the addition of beef jerky catfish ranged between $1.15 \%-1.54 \%$.

The ash content of raw materials, namely $0.86 \%$ cassava leaves, and Meat of Catfish 1.10\% .Kadar Abu increased after treatment becomes jerky, this is because at the time of boiling salted so that cassava leaves mineral elements $\mathrm{Mg}$, $\mathrm{Na}$, and $\mathrm{Cl}$ participate seep into cassava leaves when the boiling process. The purpose of giving salt when boiling is that cassava leaves no bitter taste. Provision is also made at the time of salt mixing jerky seasoning.

These results are consistent with research Salama [6] which showed that the ash content of fresh mussels increased after boiling with the addition of salt containing mineral elements, $\mathrm{Mg}, \mathrm{Na}$, and $\mathrm{Cl}$ were joined seep into the mussel meat during boiling. According to SNI [8] levels Abu Jerky is a maximum of $1 \%$, ash content jerky produced all treatment has met standards.

\section{3) Protein Analysis}

The result of statistical test to analysis of protein levels by treatment with the addition of meat jerky catfish significant effect on the real level $\alpha=5 \%$ of the protein content of 
cassava leaves produced jerky. The average value of the analysis of protein content in cassava leaves jerky meat with the addition of catfish can be seen in Table 5.

TABLE V

Results ANAlysis Of Protein LeVels JeRky CAsSAVA LEAVES

\begin{tabular}{|c|c|}
\hline Treatment & Protein Content $(\%)$ \\
\hline A (Meat of Catfish $37.5 \%$ ) & 25,09 a \\
\hline B (Meat of Catfish $50 \%$ ) & $28,26 \mathrm{~b}$ \\
\hline C (Meat of Catfish $62.5 \%)$ & $30,62 \quad \mathrm{c}$ \\
\hline D (Meat of Catfish $75 \%$ ) & $34,68 \mathrm{~cd}$ \\
\hline E (Meat of Catfish $87.5 \%$ ) & 36,20 \\
\hline F (Meat of Catfish $100 \%$ ) & 38,08 \\
\hline $\mathrm{CV}=2,99 \%$ & \\
\hline
\end{tabular}

The numbers in the same column followed by the same lowercase letters are not significantly different at the $5 \%$ significance level Duncan's Multiple Range Test (DNMRT).

The results of the analysis of protein content in cassava leaves jerky products with the addition of Meat of Catfish in Table 4 shows that the levels of protein produced ranged between $25.09 \%-38.08 \%$. The protein content was lowest for the treatment of A (Meat of Catfish 37.5\%) with an average value of $25.09 \%$, while the highest protein content contained in treatment $\mathrm{F}$ (Meat of Catfish 100\%) with an average value of $38.08 \%$.

In Table 4 it can be seen that the higher formula catfish meat is added, the higher the protein content of cassava leaves produced jerky. It is influenced by raw material catfish meat that has been analyzed to have a protein that is $18.92 \%$, while the cassava leaves have a $6.68 \%$ protein. Meat of Catfish can absorb more seasoning than cassava leaves so that the protein of Meat of Catfish will stand out.

This is in accordance with the opinion Lawrie [4] which states that the addition of a number of animal protein into a food source of vegetable protein would cause a shortage of essential amino acids in a protein which one is covered by the excess amino acids in a protein like the other, so that the nutritional quality of the mixture can be higher than one protein, thus increasing the protein content of beef jerky.

Of 6 treatments additions to catfish meat jerky produced cassava leaves only 4 treatments C, D, E, and F which meet the quality requirements of ISO (01 - 2908 to 1992) that is at least $30 \%$. This is because the protein content of beef jerky drying time increases as the temperature used is not too high. Protein levels decreased during the frying pan used for high temperatures, which can damage the protein content. This is in accordance with the opinion of Teller (1999) which states that the heating (boiling and frying) excessive or long lead time will decrease the nutritional value of protein.

\section{4) Analysis of Fat}

The result of statistical test to analysis the fat content of meat jerky with additional treatment catfish significant effect on the real level $\alpha=5 \%$ of the fat content of beef jerky produced cassava leaves. The average value analysis on the fat content of beef jerky meat cassava leaves with the addition of catfish can be seen in Table 6 .

The results of the fat content Jerky in Table 6, show that the resulting fat content ranged from $28.83 \%-33.33 \%$. Produced the highest fat content contained in treatment $\mathrm{F}$ (Meat of Catfish 100\%) with an average value of $33.33 \%$ while the lowest fat content contained in treatment A (Meat of Catfish $37.5 \%$ ) with an average value of $28.83 \%$.

TABLE VI

RESUlts ANALysis OF FAT CONTENT OF CASSAVA LEAVES JERKY

\begin{tabular}{|c|c|}
\hline Treatment & Fat Content (\%) \\
\hline A (Meat of Catfish $37.5 \%)$ & $28,83 \mathrm{ab}$ \\
\hline B (Meat of Catfish $50 \%$ ) & $29,06 \mathrm{~b}$ \\
\hline C (Meat of Catfish $62.5 \%$ ) & $29,63 \mathrm{~b}$ \\
\hline D (Meat of Catfish $75 \%$ ) & $30,94 \mathrm{~cd}$ \\
\hline E (Meat of Catfish $87.5 \%$ ) & 31,52 \\
\hline F (Meat of Catfish $100 \%$ ) & 33,33 \\
\hline $\mathrm{CV}=2,08$ & \\
\hline
\end{tabular}

The numbers in the same column followed by the same lowercase letters are not significantly different at the 5\% significance level Duncan's Multiple Range Test (DNMRT).

In Table 5 it can be seen that the higher formula catfish meat is added then increasing the fat content of beef jerky produced. It is influenced by raw material analyzed catfish meat has fat content is $1,35 \%$ while cassava leaves have a $1: 26 \%$ fat content.

Increased levels of fat after processing very significant, this is because the processing is done frying beef jerky with a certain heating temperature. At the time of frying beef jerky is able to absorb more oil, because jerky has a cavity, while the water content is reduced due to the heating process.

Soeparno [7] states that, the chemical composition of meat that is processed by the method of drying, heating and cooking at a certain temperature will cause the water content decreases while the protein and fat content increased but remained on the chemical composition of the proportional.

\section{5) Appearance}

Sensory tests conducted an A test or hedonic test. Sensory test can determine the level of A panelist on Jerky cassava leaves with the addition of Meat of Catfish through observation of color, flavor, flavor and texture were performed by 20 panelists.

Sensory tests were performed using the hedonic test hedonic scale of 1 to 5: 1 = Very Much Disliked (STS), 2 = Disliked (TS), 3 = Fair (B), $4=$ Liked (S), and $5=$ Very Much Liked (SS). Further assessment results are tabulated based on the assessment of the panelists. The figures in the table is the average of the panelists who expressed love to love and the highest value is expressed as a product test results. The result of the calculation of the Sensory test jerky meat cassava leaves with the addition of the resulting catfish can be seen in Table 7 .

TABLE VII

Percentage LeVel Of ACCEPTANCE APPEARANCE LiKed AND Very MuCH LiKed At JERKy CASSAVA LEAVES With THE ADDITION OF CATFISH MEAT

\begin{tabular}{|l|c|c|c|c|}
\hline \multirow{2}{*}{ Treatment } & \multicolumn{4}{|c|}{ Sensory Properties } \\
\cline { 2 - 5 } & Color & Flavor & Taste & Texture \\
\cline { 2 - 5 } & $(\%)$ & $(\%)$ & $(\%)$ & $(\%)$ \\
\hline A (Meat of Catfish 37.5\%) & 80 & 70 & 70 & 50 \\
\hline B (Meat of Catfish 50\% ) & 70 & 75 & 90 & 90 \\
\hline C (Meat of Catfish 62.5\%) & 70 & 85 & 70 & 60 \\
\hline D (Meat of Catfish 75\% ) & 70 & 55 & 65 & 55 \\
\hline E (Meat of Catfish 87.5\%) & 75 & 60 & 75 & 55 \\
\hline F (Meat of Catfish 100\% ) & 70 & 50 & 60 & 40 \\
\hline
\end{tabular}




\section{- Color}

Color sensory test is intended to determine the level of A panelist on Jerky color produced. Color is the result of the eye that senses could be a consideration in choosing a food product. Color is a very important component in the elucidation of quality food products because of attractive colors to attract consumers to consume a food product. Determining the quality of a food is generally dependent on the color, because color appear first [12].

Based on Table 6 shows that the color of beef jerky products cassava leaves with the addition of Meat of Catfish can be accepted by the panelists. Of the six panelists acceptance level treatment of the relative color indicates a high rate, which is more than $50 \%$ acceptance rate panelists to color jerky produced in this study ranged from $70 \%-80 \%$. Panelists who expressed love until love is highest in treatment A (Addition Meat of Catfish 37.5\%).

Color jerky generated in this study are reddish brown. Before the drying process jerky brownish green color after drying jerky color turned into a reddish brown. According Lisdiana (1997) jerky typical reddish brown color is due to the drying process, the particles will undergo non-enzymatic browning reaction (Maillard) caused by the interaction between the protein amino acids and reducing sugars that make jerky color changes.

\section{- Flavor}

Flavor is a very important component in the elucidation of quality food products for scent or smell of food much determine delicacies and the taste of food itself consists of three components, namely smell, taste and mouth stimulation [12].

Based on Table 6 shows that the scent Jerky Products cassava leaves with the addition of Meat of Catfish can be accepted by the panelists. Of six treatments are five panelists acceptance rate treatment for color figures show a relatively very high, above $50 \%$ of the stated likes to really like. The level of acceptance of the panelists on flavor jerky ranged between $50 \%-85 \%$.

Panelists who expressed love until love is highest in treatment C (Addition Meat of Catfish 62.5\%) is $85 \%$. While panelists who expressed love to really like the least are in treatment $\mathrm{F}$ (Addition Meat of Catfish 100\%) is $50 \%$.

Rate this scent using the sense of smell. According Winarno [12], stated that in many ways determined by the flavor of delicious food or the smell of the food. Flavor Jerky generated in this study are typical flavor of beef jerky. According Harefa (2010), distinctive flavor jerky occurs during drying which causes the formation of volatile compounds. This causes a distinctive flavor jerky given panelists preferred.

\section{- Taste}

Taste can be assessed by the presence of a chemical reaction by the senses taster. Taste is a very important factor in determining the final decision to accept or reject the consumer food product.

Based on Table 6 shows that the taste of beef jerky products with the addition of Meat of Catfish can be accepted by the panelists. Of all treatment levels of acceptance of the taste panelists indicate relatively high level of above $50 \%$ who expressed love to love. The level of acceptance of panelists to taste jerky produced in this study ranged from $60 \%-90 \%$. Panelists stated Likes to really like is highest in treatment B (Addition Meat of Catfish 50\%) is $90 \%$, while the panelists stated like to very low like there In the treatment $\mathrm{F}$ (Addition Meat of Catfish 100\%) ie $60 \%$.

Taste plays an important role of the existence of a food product. Although the color and flavor of good food, but it feels uncomfortable then consumers will reject the product. The resulting flavor of jerky cassava leaves with the addition of Meat of Catfish provide meat taste delicious, so many panelists who love jerky products cassava leaves with the addition of catfish meat is that it tastes similar to beef jerky. Flavor that resembles meat jerky seasoning is due to the formula used is similar to beef jerky seasoning meat.

\section{- Texture}

Jerky is a semi-moist food, after going through several processing jerky has a savory and crunchy texture, depending on the thickness of the fillet itself, increasingly thin jerky produced the more savory texture of beef jerky.

Based on Table 6 shows that the texture of beef jerky products cassava leaves with the addition of Meat of Catfish can be accepted by the panelists. Of the six treatment there are four panelists acceptance treatment above $50 \%$. The level of acceptance of the panelists on the relative texture showed a high rate, which is more than $50 \%$ of panelists expressed love to love. The level of acceptance of the panelists on the texture of beef jerky produced in this study ranged from $40 \%-90 \%$.

Panelists who expressed love until love is highest in treatment B (Addition Meat of Catfish 50\%) is 90\%. While the panelists acceptance of the lowest for the treatment of texture F (Addition Meat of Catfish $100 \%$ ) is $40 \%$.

Here is a list of chart results in all treatments and sensory properties assessed panelists, namely in the form of color, flavor, flavor, and texture. Can be seen in the image below:

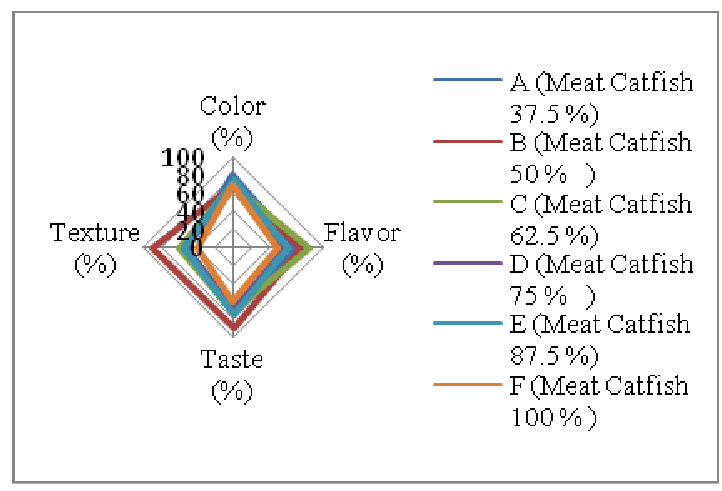

Fig. 1. Radar Level Panelists passions on Jerky Products Cassava Leaves with Meat of Catfish Addition to Color, Flavor, Taste and Texture.

Based on the image above, shows that the radar assessment of the jerky panelists cassava leaves for all treatments A, B, C, D, E, and F preferred by the panelists. The best jerky products according to panelists assessment is in treatment B (Meat of Catfish 50\%). Flavor panelists preferred product is treatment $\mathrm{C}$ (Meat of Catfish 62.5\%), the most preferred product taste panelists were treatment $\mathrm{B}$ 
(Meat of Catfish 50\%), and the texture of the products most preferred by the panelists was treatment B (Meat of Catfish $50 \%)$. So that the best products are the most preferred product panelist treatment B (Meat of Catfish 50\%). While the product is less favored panelists are in treatment $\mathrm{F}$ (Meat of Catfish 100\%).

\section{CONCLUSIONS}

Based on the research that has been done can be concluded as follows: (1) The rate of addition of beef jerky catfish against cassava leaves very real effect on the improvement of cassava leaf protein produced jerky; (2) The best treatment in jerky products produced by the panel assessment, contained in treatment B (Meat of Catfish 50\%) the color with an average value of $70 \%$, with a mean value Flavor rata $75 \%$, Taste with an average rating of $90 \%$, and Texture with an average value of $90 \%$.

Based on the research that has been done, there are some suggestions for further research, namely: (1) Observation of moisture, ash, protein, and fat should be done before frying, to be compared with SNI (Indonesian national Standard); (2) The addition of seasonings formula should be increased along with the increasing addition of Meat of Catfish formula, so that the resulting jerky marinade flavor more pronounced; (3) Excision jerky should be uniform.

\section{ACKNOWLEDGMENT}

Thank you to Dean Faculty of Agricultural Technology Andalas University and thank to organizing committee International Conference on Quality Improvement and Development of Food Product (QID-Food 2015) for publishing this article.

\section{REFERENCES}

[1] Harris, R. 1989. Evaluation of Nutrition in Food Processing. ITB: Bandung.

[2] Hawab, HM 1999. The effect of heating the rice into the rice as the decline in the value of variable nutrient rice. Chemical Bulletin No. 14 things 69-80.

[3] The cashier, WK 1999. Comparative study of chemical and sensory properties of shredded beef, chicken, rabbit. Thesis. Faculty of Animal Husbandry. Institut Pertanian Bogor. Bogor.

[4] Lawrie, R.A. 1995. Meat Science. Fifth edition. Translations Aminuddin Parakkasi \& Yuda Amwila. University of Indonesia (UIPress): Jakarta.

[5] Lisdiana, F. 1997. Making Jerky Arts. Canisius: Yogyakarta.

[6] Salamah, E. Purwaningsih, S. Kurnia, R. Journal of Mineral Content Mussels (Corbicula javanica) Due Process Processing. 2012. Institute for Agriculture, Bogor. Bogor.

[7] Soeparno. 2011. Nutrition and Nutrition Meat. Moulds to-1. Gadjah Mada University Press: Yogyakarta.

[8] SNI [Indonesian National Standard]. 1992. SNI 01-2908-1992. Beef Jerky. BSN, Jakarta.

[9] Suharyanto. 2007. Characteristics Minced Meat Jerky In Laundering (Leaching) and Different Type meat. [Thesis]. Post graduate school IPB Bogor.

[10] Winarno, F.G., S. Fardiaz, \& D. Fardiaz. 1984.Pengantar Food Technology. PT. Gramedia Pustaka Utama: Jakarta.

[11] Winarno, F. G. 1997. The Chemistry of Food and Nutrition. Publisher PT. Gramedia Pustaka Utama. Jakarta.

[12] Winarno. 2002. Chemistry of Food and Nutrition. PT. Scholastic. Jakarta 